\title{
Removal of the Chiral Inductor from Phenylglycinol-derived Tricyclic Lactams. Unexpected Generation of Chiral trans-Hydrochromene Lactones
}

\author{
Rosa Griera, Alexandre Pinto, Robert Fabregat, Èric Cots, Joan Bosch , and Mercedes Amat*
}

Laboratory of Organic Chemistry, Faculty of Pharmacy and Food Sciences, and Institute of Biomedicine (IBUB), University of Barcelona, 08028-Barcelona, Spain

\begin{abstract}
In the search for synthetic routes for the preparation of cis- and trans- decahydroquinolin-2-ones, a procedure for the generation of enantiopure trans-hydrochromene lactones, by treatment of $(R)$-phenylglycinol-derived oxazoloquinolone lactams with $\mathrm{Na}$ /liq. $\mathrm{NH}_{3}$ followed by acidification, has been developed.
\end{abstract}

Keywords: Decahydroquinoline, debenzylation, lactams, lactones, perhydrochromene, sodium-ammonia.

Dedicated to Prof. Miguel Yus on the occasion of his $70^{\text {th }}$ birthday

\section{INTRODUCTION}

Chiral aminoalcohol-derived tricyclic lactams have proven to be excellent optically enriched scaffolds for the synthesis of cis-decahydroquinolines (DHQs) and cis- and trans-octahydroindoles. ${ }^{[1-5]}$ In previous work we have reported the enantioselective synthesis of a variety of natural products, such as $\alpha$-lycorane,,$^{[1]}$ Myrioneuron alkaloids, ${ }^{[2]}$ pumiliotoxin $C_{1}{ }^{[3]}$ ent-2-epi-pumiliotoxin $C_{1}{ }^{[3 b]}$ cermizine $B,{ }^{[4]}$ and the marine alkaloids lepadins $A-D,{ }^{[5]}$ from chiral tricyclic lactams, thus demonstrating their value in the field of total synthesis. One of the key steps in the above transformations is the removal of the phenylethanol moiety of the chiral inductor. This is usually accomplished in excellent yield and stereoselectivity in two steps: alane reduction, which brings about the reduction of the lactam carbonyl and the $\mathrm{C}-\mathrm{O}$ bond of the oxazolidine ring, and catalytic hydrogenation, with concomitant protection by $\mathrm{Boc}_{2} \mathrm{O}$, to promote the reductive cleavage of the benzylic C$\mathrm{N}$ bond. Scheme 1 illustrates the preparation of cis-DHQs 3 and $\mathbf{4}$ from lactams $\mathbf{1}$ and $\mathbf{2}$, respectively. ${ }^{[5 a, 6]}$
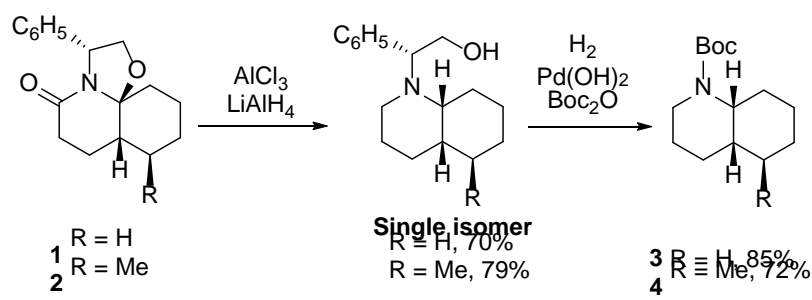

Scheme 1. Stereoselective removal of the chiral inductor to give cis-DHQs.

*Address correspondence to this author at the Department of Pharmacology, Toxicology and Therapeutic Chemistry, Faculty of Pharmacy and Food Sciences, University of Barcelona, 08028-Barcelona, Spain; Tel: +34-93-402-4540, Fax: +34-93-402-4539; E-mail: amat@ub.edu
Alternatively, the removal of the phenylethanol moiety to give cis-bicyclic lactams (for instance, $\mathbf{5}$ and $\mathbf{6}$ ) has previously been accomplished in the fused 5-5-6-membered and bridged 5-6-7-membered series by cleavage of the oxazolidine $\mathrm{C}-\mathrm{O}$ bond with a trialkyl- or triarylsilane under acidic conditions, followed by $\mathrm{N}$-debenzylation of the resulting lactam with sodium in liquid ammonia, as outlined in Scheme $2^{[1,7]}$

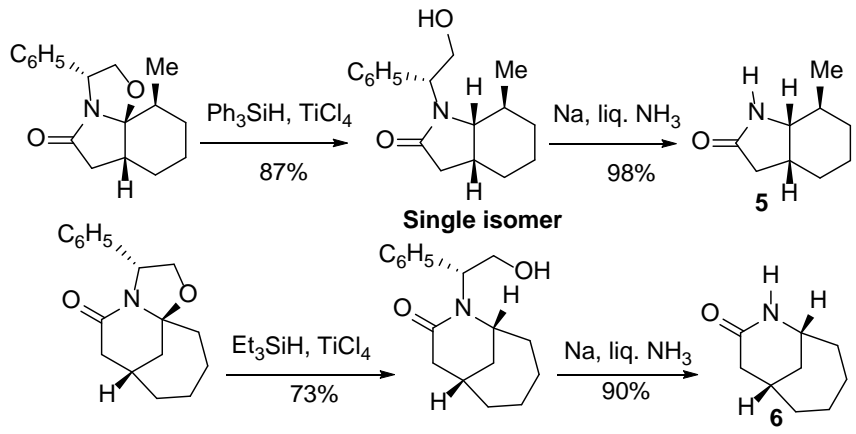

Scheme 2. Generation of cis-bicyclic lactams from phenylglycinolderived tricyclic lactams.

\section{RESULTS AND DISCUSSION}

We were now interested in exploring procedures for the conversion of the above 5-6-6-membered tricyclic lactams 1 and 2 (A, Figure 1) into cis- and trans-octahydroquinolin-2ones. The functionalization at the piperidine 2 position may be harnessed for the synthesis of complex DHQ targets.

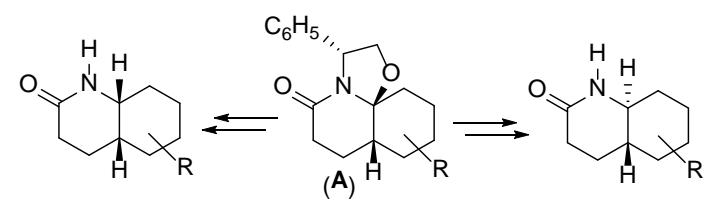

Figure 1. Cis- and trans-octahydroquinolin-2-ones by from chiral 56-6-membered tricyclic lactams.

C 2017 Bentham Science Publishers 
The excellent results obtained by the procedure outlined in Scheme 2 prompted us to use it for the synthesis of cisdecahydroquinolin-2-ones. However, the chemoselective reduction of the oxazolidine ring of $\mathbf{2}$ required treatment with $\mathrm{TiCl}_{4}$ (3 equiv) and an excess of triethylsilane (3 equiv) for more than $70 \mathrm{~h}$. Moreover, the reaction took place in moderate yield and low stereoselectivity to give a 5:1 mixture of cis- and trans-isomers $7 \mathbf{a}$ and $\mathbf{7 b}$, which could not be separated by column chromatography. The subsequent debenzylation of these isomers with sodium and liquid ammonia afforded a mixture of the corresponding decahydroquinolin-2-ones (87\%), from which the cis-isomer 8 could be separated by crystallization. This lactam had previously been converted ${ }^{[8]}$ into the amphibian alkaloid pumiliotoxin C (Scheme 3 ).

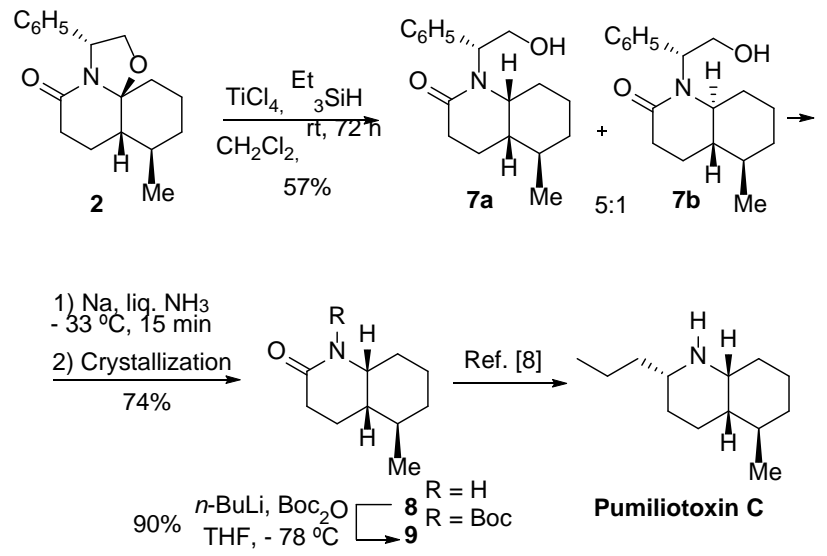

Scheme 3. Access to cis-decahydroquinolin-2-ones from 5-6-6membered tricyclic lactams.

To improve the above results in terms of both chemical yield and stereoselectivity, we developed an alternative procedure leading to cis-decahydroquinolin-2-ones, involving the ruthenium tetroxide oxidation of cis-DHQs. Thus, treatment of cis-DHQ 3 with ruthenium tetroxide gave decahydroquinolin-2-one $\mathbf{1 0}$ in excellent yield. A similar oxidation of the methyl substituted tricyclic lactam 4 afforded cis-decahydroquinolin-2-one $\mathbf{9}$ in high yield ${ }^{[5]}$ (Scheme 4).

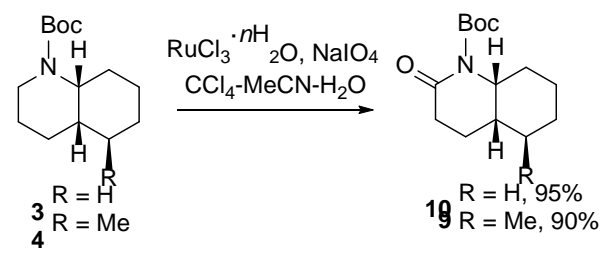

Scheme 4. Oxidation of cis-DHQs to cis-decahydroquinolin-2-ones

Taking into account the transformations depicted in Scheme 1, conversion of tricyclic lactams $\mathbf{1}$ and $\mathbf{2}$ into the cis bicyclic lactams $\mathbf{1 0}$ and $\mathbf{9}$ requires three synthetic steps and takes place in $57 \%$ and $51 \%$ overall yield, respectively.

With a method in hand for the efficient preparation of enantiopure cis-decahydroquinolin-2-ones from chiral tricyclic lactams, the next goal was to set up a procedure for the synthesis of trans isomers.

In view of the reported $\mathrm{Et}_{3} \mathrm{SiH}_{-} \mathrm{TiCl}_{4}$ stereoselective reduction of 8a-hydroperoxy-2-oxoperhydroquinolines (11) to the corresponding trans-decahydroquinolones $(\mathbf{1 2})^{[9]}$ (Scheme 5), we envisaged an alternative way to remove the chiral inductor. It involves the $\mathrm{Na} /$ liq. $\mathrm{NH}_{3}$-promoted reductive cleavage of the benzylic $\mathrm{C}-\mathrm{N}$ bond ${ }^{[10]}$ and the subsequent $\mathrm{Et}_{3} \mathrm{SiH}$ reduction of the resulting 8aoxyperhydroquinolone intermediate $\mathbf{B}$, which was expected to provide the desired trans ring junction (i. e. 13).



Scheme 5. Stereoselective generation of trans-decahydroquinolin2-ones. [9]

However, reduction of lactam 2 with sodium in liquid ammonia under the usual conditions for the $\mathrm{N}$ debenzylation $\left(\mathrm{THF},-33{ }^{\circ} \mathrm{C}, 1 \mathrm{~min}\right.$; then $\mathrm{NH}_{4} \mathrm{Cl}$ and filtration through Celite $\left.{ }^{\circledR}\right)$, followed by treatment of the resulting crude mixture with $\mathrm{Et}_{3} \mathrm{SiH}$ in the presence of $\mathrm{TiCl}_{4}$ under the conditions used in the preparation of 7 , did not afford the expected $N$-unsubstituted lactam 13. Lactone 14 was isolated in $40 \%$ yield instead (Scheme 6). Phenylethanol, arising from the reductive cleavage of the phenylglycinol moiety, was also isolated. Hydroxy acid $\mathbf{C}$ was detected by $\mathrm{GC} / \mathrm{MS}$ ( $\mathrm{m} / \mathrm{z}$ 186) from the crude mixture after the $\mathrm{Na} / \mathrm{liq}$. $\mathrm{NH}_{3}$ reduction, and attempts to purify it by column chromatography $\left(\mathrm{SiO}_{2}\right)$ or by acidic work-up resulted in the formation of lactone 14.



Scheme 6. Unexpected generation of a perhydrochromene lactone.

The above results made evident that the intermediate $\mathbf{B}$ formed after $N$-debenzylation, before it could undergo the expected $\mathrm{Et}_{3} \mathrm{SiH} / \mathrm{TiCl}_{4}$-promoted reduction, is further reduced in situ to hydroxy acid $\mathbf{C}$, which is converted to lactone $\mathbf{1 4}$ under acidic conditions.

The ${ }^{1} \mathrm{H}$ - and ${ }^{13} \mathrm{C}$-NMR data of lactone 14 were quite similar to those expected for lactam 13, except for the 
deshielding observed for the proton ( $\delta 3.95 \mathrm{ppm})$ and carbon ( $\delta 82.8 \mathrm{ppm}$ ) at position $8 \mathrm{a}$. The HRMS data confirmed the structural assignment. The trans ring fusion of the lactone ring was deduced from the coupling constants $(J=10.9,9.9$, and $4.3 \mathrm{~Hz})$ of the methine $8 \mathrm{a}$ proton. ${ }^{[11]}$

The yield of lactone $\mathbf{1 4}$ was improved by omitting the superfluous $\mathrm{Et}_{3} \mathrm{SiH} / \mathrm{TiCl}_{4}$ treatment and promoting the lactonization of the intermediate hydroxy acid $\mathbf{C}$ using concentrated hydrochloric acid $(\mathrm{pH}=1-2$; see Experimental Section). Under these conditions, enantiopure lactone $\mathbf{1 4}$ was obtained in $60 \%$ yield (Scheme 7 ).
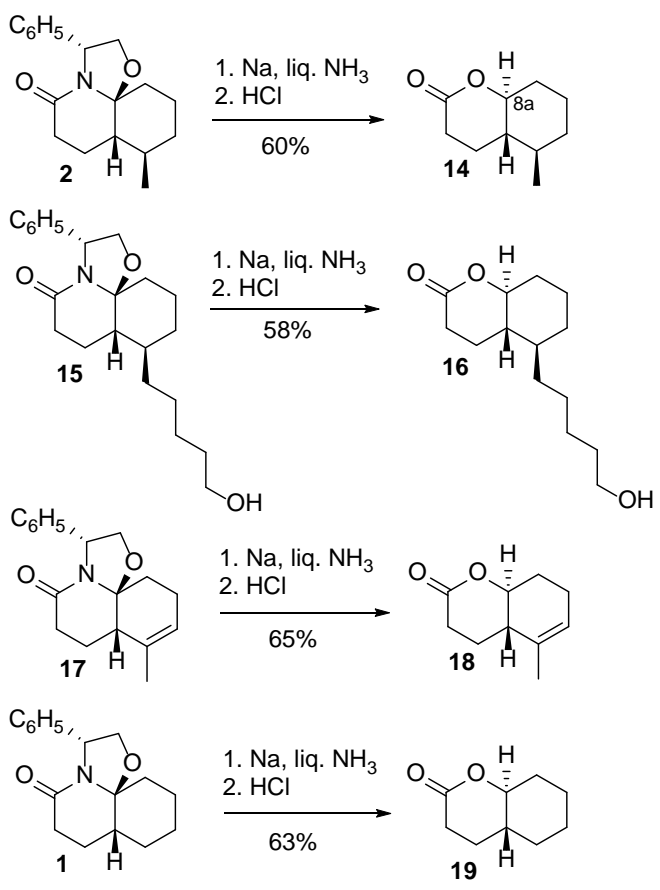

Scheme 7. Conversion of phenylglycinol-derived oxazoloquinolone lactams to trans-hydrochromene lactones.

Taking into account that we have previously developed a general procedure for the preparation of $(R)$-phenylglycinolderived tricyclic lactams, by cyclocondensation of this amino alcohol with appropriate cyclohexanone-based $\delta$-keto esters, ${ }^{[2-6,12]}$ we envisaged these lactams as general synthetic precursors of enantiopure trans-hydrochromene lactones. Thus, following the above procedure, lactam 15, prepared by desilylation (TBAF) of the corresponding TBDMS derivative, ${ }^{[5 b]}$ was satisfactorily converted to enantiopure trans-lactone 16. Similarly, unsaturated lactone 18 and unsubstituted lactone $\mathbf{1 9}$ were prepared in acceptable yields from the corresponding tricyclic lactams 17 and $1,^{[5]}$ respectively. In all cases, the trans ring fusion of the lactone ring was established from the coupling constants of the methine 8 a proton. ${ }^{[11]}$ Additionally, the optical purity of lactone 19 was confirmed by its $[\alpha]_{D}$ value, which matched that reported in the literature for this compound. [13]

\section{CONCLUSION}

A convenient procedure for the conversion of tricyclic phenylglycinol-derived oxazoloquinolone lactams to enantiopure trans-hydrochromene lactones, including derivatives bearing an additional stereocenter at the C-5 position, has been developed.

Mechanistic aspects of this unprecedented transformation will be investigated and its scope and application in the synthesis of natural products explored in further studies.

\section{EXPERIMENTAL SECTION}

(4aS,5R,8aR)-1-[(1R)-2-Hydroxy-1-phenylethyl]-5-methyl-2oxodecahydroquinoline (7): $\mathrm{TiCl}_{4}(230 \mu \mathrm{L}, 2.11 \mathrm{mmol})$ was added to a solution of lactam $2(200 \mathrm{mg}, 0.70 \mathrm{mmol}$ ) in anhydrous $\mathrm{CH}_{2} \mathrm{Cl}_{2}(4 \mathrm{~mL})$ at $-78{ }^{\circ} \mathrm{C}$ and the mixture was stirred for $30 \mathrm{~min}$. Et ${ }_{3} \mathrm{SiH}(340 \mu \mathrm{L}, 2.11 \mathrm{mmol})$ was added and the solution stirred at $-78{ }^{\circ} \mathrm{C}$ for $45 \mathrm{~min}$. The reaction mixture was allowed to warm to room temperature and stirred for 72 h. Saturated aqueous $\mathrm{NaHCO}_{3}$ was added, and the resulting mixture was extracted with $\mathrm{CH}_{2} \mathrm{Cl}_{2}$. The combined organic extracts were washed with brine, dried over anhydrous $\mathrm{MgSO}_{4}$, filtered, and concentrated. Flash chromatography (EtOAc) afforded a mixture (5:1, cis:trans) of lactams $7 \mathbf{a}$ and $\mathbf{7 b}(116 \mathrm{mg}, 57 \%)$ as a colorless oil: ${ }^{1} \mathrm{H}$ NMR $\left(400 \mathrm{MHz}, \mathrm{CDCl}_{3}\right) \delta: 0.99\left(\mathrm{~d}, J=7.6 \mathrm{~Hz}, 3 \mathrm{H}, \mathrm{CH}_{3}\right), 1.23-$ $1.79(\mathrm{~m}, 11 \mathrm{H}, \mathrm{H}-7, \mathrm{H}-11), 1.81-1.94(\mathrm{~m}, 2 \mathrm{H}, \mathrm{H}-7 \mathrm{a}, \mathrm{H}-8)$, 2.07$2.18(\mathrm{~m}, 1 \mathrm{H}, \mathrm{H}-7), 2.53-2.59(\mathrm{~m}, 2 \mathrm{H}, \mathrm{H}-6), 3.32(\mathrm{dt}, J=11.2$, $4.3 \mathrm{~Hz}, 1 \mathrm{H}, \mathrm{H}-11 \mathrm{a}), 4.04$ (dd, $J=11.6,3 \mathrm{~Hz}, 1 \mathrm{H}, \mathrm{H}-2), 4.26-$ $4.36(\mathrm{~m}, 1 \mathrm{H}, \mathrm{H}-2), 4.57$ (dd, $J=6.4,2.6 \mathrm{~Hz}, 1 \mathrm{H}, \mathrm{H}-3), 7.26$ 7.30 (m, 3H, H-Ar), 7.32-7.35 (m, 3H, H-Ar); ${ }^{13} \mathrm{C}-\mathrm{NMR}(100.6$ $\left.\mathrm{MHz}, \mathrm{CDCl}_{3}\right) \delta: 19.0\left(\mathrm{CH}_{3}\right), 19.7$ (C-10), 22.5 (C-7), 26.1 (C11), 28.1 (C-9), 32.0 (C-6), 33.2 (C-8), 40.1 (C-7a), 57.1 (C11a), 64.8 (C-2), 66.6 (C-3), 127.2 ( $\mathrm{CH}-o), 127.4(\mathrm{CH}-p), 128.6$ (CH-m), 137.2 (Cq-Ar), 172.0 (NCO); HRMS calcd for $\left[\mathrm{C}_{18} \mathrm{H}_{25} \mathrm{NO}_{2}+\mathrm{H}^{+}\right]$: 288.1958, found 288.195.

(4aS,5R,8aR)-5-Methyl-2-oxodecahydroquinoline (8): Into a three-necked, $100 \mathrm{~mL}$, round-bottomed flask equipped with a coldfinger condenser charged with dry ice-acetone, $\mathrm{NH}_{3}$ was condensed $(30 \mathrm{~mL})$ at $-78{ }^{\circ} \mathrm{C}$. Then, a $5: 1$ mixture of lactams 7a and 7b (400 mg, $1.39 \mathrm{mmol})$ in anhydrous THF (2 $\mathrm{mL}$ ) was added and the temperature was raised to $-33^{\circ} \mathrm{C}$. Sodium metal was added in small portions until the blue color persisted, and the mixture was stirred at $-33^{\circ} \mathrm{C}$ for 15 min. The reaction was quenched by addition of $\mathrm{NH}_{4} \mathrm{Cl}$ until the blue color disappeared, and then the mixture was stirred at room temperature for $4 \mathrm{~h}$. The resulting residue was dissolved in water and extracted with $\mathrm{CH}_{2} \mathrm{Cl}_{2}$. The combined organic extracts were dried over anhydrous $\mathrm{Na}_{2} \mathrm{SO}_{4}$, filtered, and concentrated. Flash chromatography (7:3 hexane-EtOAc to AcOEt) afforded a 5:1 mixture of 
lactam 8 and its trans isomer ( $202 \mathrm{mg}, 87 \%$ ) as a white solid. Crystallization from AcOEt afforded pure 8 (173 mg, 74\%): ${ }^{1} \mathrm{H}$ NMR $\left(400 \mathrm{MHz}, \mathrm{CDCl}_{3}\right) \delta: 0.93\left(\mathrm{~d}, J=6.4 \mathrm{~Hz}, 3 \mathrm{H}, \mathrm{CH}_{3}\right)$, 0.99-1.09 (m, $1 \mathrm{H}), 1.39-1.71(\mathrm{~m}, 8 \mathrm{H}), 2.00-2.10(\mathrm{~m}, 1 \mathrm{H})$, 2.26-2.32 (m, 2H), 3.59-3.64 (m, $1 \mathrm{H}, \mathrm{H}-8 \mathrm{a}), 5.90$ (bs, $1 \mathrm{H}$, $\mathrm{NH}) ;{ }^{13} \mathrm{C}$ NMR $\left(100.6 \mathrm{MHz}, \mathrm{CDCl}_{3}\right) \delta: 19.3\left(\mathrm{CH}_{3}\right), 20.0\left(\mathrm{CH}_{2}\right)$, $23.1\left(\mathrm{CH}_{2}\right), 27.3\left(\mathrm{CH}_{2}\right), 27.6(\mathrm{CH}), 31.8\left(\mathrm{CH}_{2}\right), 33.7\left(\mathrm{CH}_{2}\right), 39.7$ (CH), $52.2(\mathrm{CH}), 172.9$ (NCO).

(4aS,5R,8aR)-1-(tert-Butoxycarbonyl)-5-methyl-2-oxodecahydroquinoline (9): $n$-BuLi $(680 \mu \mathrm{L}$ of a $1.6 \mathrm{M}$ solution in hexane, $1.09 \mathrm{mmol}$ ) was added dropwise to a solution of compound 8 (173 $\mathrm{mg}, 1.03 \mathrm{mmol})$ in anhydrous THF (12 mL) at $-78{ }^{\circ} \mathrm{C}$. After $30 \mathrm{~min}$, a solution of $\mathrm{Boc}_{2} \mathrm{O}(340 \mathrm{mg}, 1.55$ mmol) in anhydrous THF (3.1 $\mathrm{mL})$ was added, and the mixture was stirred for $1 \mathrm{~h} 30 \mathrm{~min}$ at $-78^{\circ} \mathrm{C}$. Saturated aqueous $\mathrm{NH}_{4} \mathrm{Cl}$ was added, and the mixture was extracted with EtOAc. The combined organic extracts were dried over anhydrous $\mathrm{Na}_{2} \mathrm{SO}_{4}$, filtered, and concentrated. Flash chromatography (7:3 hexane-EtOAc) afforded lactam 9 (250 $\mathrm{mg}, 90 \%)$ as a white solid: $\mathrm{mp} 99-102{ }^{\circ} \mathrm{C} ;[\alpha]^{23} \mathrm{D}=-23.92(\mathrm{c}$ 1.0, $\mathrm{CHCl}_{3}$ ); IR (film): $1765,1712 \mathrm{~cm}^{-1}$; ${ }^{1} \mathrm{H}-\mathrm{NMR}(400 \mathrm{MHz}$, $\left.\mathrm{CDCl}_{3}\right) \delta: 1.08\left(\mathrm{~d}, J=7.3 \mathrm{~Hz}, 3 \mathrm{H}, \mathrm{CH}_{3}\right), 1.20-1.28(\mathrm{~m}, 1 \mathrm{H}, \mathrm{H}-7)$, 1.45-1.68 (m, 5H, H-4, H-6, H-7, H-8), 1.51 [s, 9H, C( $\left.\left.\mathrm{CH}_{3}\right)_{3}\right]$, 1.76-1.93 (m, 3H, H-4a, H-5, H-6), 2.05-2.17 (m, 1H, H-4), 2.39-2.59 (m, 2H, H-3), 4.13-4.21 (m, $1 \mathrm{H}, \mathrm{H}-8 \mathrm{a}) ;{ }^{13} \mathrm{C}-\mathrm{NMR}$ $\left(100.6 \mathrm{MHz}, \mathrm{CDCl}_{3}\right) \delta: 19.0\left(\mathrm{CH}_{3}\right), 19.8$ (C-7), 23.0 (C-4), 27.2 (C-7), $27.9\left[\left(\mathrm{CH}_{3}\right)_{3} \mathrm{C}\right], 28.7$ (C-6), 32.6 (C-5), 33.4 (C-3), 39.3 (C-4a), 54.6 (C-8a), 82.7 [( $\left.\left.\mathrm{CH}_{3}\right)_{3} \mathrm{C}\right], 153.3$ (CO), 171.4 (C-2); HRMS calcd for $\left[\mathrm{C}_{15} \mathrm{H}_{25} \mathrm{NO}_{3}+\mathrm{Na}^{+}\right]$: 290.1727, found 290.1723.

\section{(4aS,8aR)-1-(tert-Butoxycarbonyl)-2-oxodecahydro-}

quinoline (10): $\mathrm{NaIO}_{4}(644 \mathrm{mg}, 3.01 \mathrm{mmol})$ and $\mathrm{RuCl}_{3} \cdot n \mathrm{H}_{2} \mathrm{O}$ (6.3 $\mathrm{mg}, 0.0301 \mathrm{mmol}$ ) were added to a heterogenous solution of $3(72 \mathrm{mg}, 0.301 \mathrm{mmol})$ in $\mathrm{CCl}_{4}-\mathrm{MeCN}-\mathrm{H}_{2} \mathrm{O}(1.7$ $\mathrm{mL}, 3: 3: 4)$ at $0{ }^{\circ} \mathrm{C}$. The mixture was stirred at $0{ }^{\circ} \mathrm{C}$ for $5 \mathrm{~min}$ and at room temperature for $5 \mathrm{~h}$. Then, EtOAc was added, the resulting mixture was filtered through Celite ${ }^{\circledR}$, and the filtrate was concentrated. Flash chromatography $(4: 6$ hexane-EtOAc) afforded $\mathbf{1 0}(72 \mathrm{mg}, 95 \%)$ as a colorless oil: $[\alpha]^{23}{ }_{D}=+2.19$ (c 1.0, MeOH); IR (film): 1765, $1712 \mathrm{~cm}^{-1} ;{ }^{1} \mathrm{H}-$ NMR (400 MHz, CDCl $)$ ) $:$ 1.24-1.55 (m, 5H, H-4, H-5, H-7, H8), 1.48 (br s, $\left.9 \mathrm{H}, 3 \mathrm{CH}_{3}\right), 1.58-1.74(\mathrm{~m}, 3 \mathrm{H}, \mathrm{H}-5, \mathrm{H}-6), 1.87-$ $1.92(\mathrm{~m}, 1 \mathrm{H}, \mathrm{H}-8), 2.02 .-2.12(\mathrm{~m}, 2 \mathrm{H}, \mathrm{H}-4, \mathrm{H}-4 \mathrm{a}), 2.41-2.58$ $(\mathrm{m}, 2 \mathrm{H}, \mathrm{H}-3), 3.99-4.04(\mathrm{~m}, 1 \mathrm{H}, \mathrm{H}-8 \mathrm{a}) ;{ }^{13} \mathrm{C}-\mathrm{NMR}(100.6 \mathrm{MHz}$, $\left.\mathrm{CDCl}_{3}\right)$ 8: 20.0 (C-7), 21.3 (C-4), 25.1 (C-5), $27.9\left[\left(\mathrm{CH}_{3}\right)_{3} \mathrm{C}\right]$, 28.2 (C-8), 30.3 (C-6), 33.3 (C-4a), 34.0 (C-3), 58.0 (C-8a), $82.6\left[\left(\mathrm{CH}_{3}\right)_{3} \mathrm{C}\right], 152.8(\mathrm{CO}), 171.2$ (C-2); HRMS calcd for $\left[\mathrm{C}_{14} \mathrm{H}_{23} \mathrm{NO}_{3}+\mathrm{Na}^{+}\right]$: 276.1570, found 276.1574 .

General Procedure for the $\mathrm{Na} /$ liq. $\mathrm{NH}_{3}$ Reduction of Lactams 2, 15, 17, and 1.

Into a three-necked, $100 \mathrm{~mL}$, round-bottomed flask equipped with a coldfinger condenser charged with dry ice- acetone, $\mathrm{NH}_{3}$ was condensed $(30 \mathrm{~mL})$ at $-78{ }^{\circ} \mathrm{C}$. Then, a solution of lactam $(1 \mathrm{mmol})$ in anhydrous THF $(5 \mathrm{~mL})$ was added and the temperature was raised to $-33^{\circ} \mathrm{C}$. Sodium metal was added in small portions until the blue color persisted, and the mixture was stirred at $-33{ }^{\circ} \mathrm{C}$ for 30 seconds. The reaction was quenched by addition of $\mathrm{NH}_{4} \mathrm{Cl}$ until the blue color disappeared, and then the mixture was stirred at room temperature for $4 \mathrm{~h}$. The resulting residue was dissolved with water and $\mathrm{CH}_{2} \mathrm{Cl}_{2}$, the two phases were separated, and the organic phase was discarded. The aqueous phase was acidified with concentrated $\mathrm{HCl}$ until $\mathrm{pH}=1-2$, and the resulting solution was stirred for $24 \mathrm{~h}$. The aqueous solution was extracted with $\mathrm{CH}_{2} \mathrm{Cl}_{2}$, and the combined organic extracts were dried over anhydrous $\mathrm{Na}_{2} \mathrm{SO}_{4}$, filtered, and concentrated to afford the corresponding lactone.

(4aS,5R,8aS)-5-Methyl-2-oxooctahydrochromene (14): $[\alpha]^{22}{ }_{D}-72.8$ (c, 0.5, MeOH); ${ }^{1} \mathrm{H}$ NMR $\left(\mathrm{CDCl}_{3}, 400 \mathrm{MHz}\right) \delta$ : $0.97\left(\mathrm{~d}, J=6.3 \mathrm{~Hz}, 3 \mathrm{H}, \mathrm{CH}_{3}\right), 1.02-1.10(\mathrm{~m}, 1 \mathrm{H}), 1.12-1.20(\mathrm{~m}$, $1 \mathrm{H}), 1.29-1.55(\mathrm{~m}, 3 \mathrm{H}), 1.63-1.73(\mathrm{~m}, 2 \mathrm{H}), 1.77-1.87(\mathrm{~m}, 1 \mathrm{H})$, 2.03-2.16 (m, $2 \mathrm{H}), 2.45-2.59(\mathrm{~m}, 1 \mathrm{H}, \mathrm{H}-3), 2.68(\mathrm{ddd}, J=$ $17.8,8.1,4.3 \mathrm{~Hz}, 1 \mathrm{H}, \mathrm{H}-3$ ), 3.95 (ddd, $J=10.9,9.9,4.3 \mathrm{~Hz}$, $1 \mathrm{H}, \mathrm{H}-8 \mathrm{a}) ;{ }^{13} \mathrm{C}$ NMR $\left(\mathrm{CDCl}_{3}, 100.6 \mathrm{MHz}\right)$ 8: $19.0\left(\mathrm{CH}_{3}\right), 23.5$ (C-7), 23.9 (C-4), 29.6 (C-3), 32.4 (C-8), 34.5 (C-6), 36.3 (C-5), 44.8 (C-4a), 82.9 (C-8a), 171.9 (C-2); HRMS calcd for $\left[\mathrm{C}_{10} \mathrm{H}_{16} \mathrm{O}_{2}+\mathrm{H}^{+}\right]: 169.1223$, found 169.1223 .

(4aS,5R,8aS)-5-(5-Hydroxypentyl)-2-oxooctahydrochromene (16): $[\alpha]^{22} \mathrm{D}-61.5$ (c, 1.3, MeOH); IR ( $\left.\mathrm{NaCl}\right): 3429$, $1734 \mathrm{~cm}^{-1} ;{ }^{1} \mathrm{H}-\mathrm{NMR}\left(\mathrm{CDCl}_{3}, 400 \mathrm{MHz}\right) \delta: 0.88-1.61(\mathrm{~m} 14 \mathrm{H})$, 1.78-1.88 (m, 2H), 2.06-2.14 (m, 2H), 2.51 (ddd, $J=17.6,8.4$, $8.2 \mathrm{~Hz}, 1 \mathrm{H}, \mathrm{H}-3$ ), 2.67 (dd, J = 18.0, 8.2, $4.6 \mathrm{~Hz}, 1 \mathrm{H}, \mathrm{H}-3$ ), 3.65 (t, $J=6.6 \mathrm{~Hz}, 2 \mathrm{H}, \mathrm{H}-5^{\prime}$ ), 3.95 (ddd, $J=10.5,10.4,4.2 \mathrm{~Hz}, 1 \mathrm{H}$, $\mathrm{H}-8 \mathrm{a}) ;{ }^{13} \mathrm{C}-\mathrm{NMR}\left(\mathrm{CDCl}_{3}, 100.6 \mathrm{MHz}\right) \delta: 23.3\left(\mathrm{CH}_{2}\right), 23.6\left(\mathrm{CH}_{2}\right)$, $26.0\left(\mathrm{CH}_{2}\right), 26.1\left(\mathrm{CH}_{2}\right), 29.4(\mathrm{C}-3), 30.7\left(\mathrm{CH}_{2}\right), 32.2\left(\mathrm{CH}_{2}\right), 32.4$ $\left(\mathrm{CH}_{2}\right), 32.7\left(\mathrm{CH}_{2}\right), 40.9$ (C-5), 42.9 (C-4a), $62.9\left(\mathrm{C}-5^{\prime}\right), 82.9$ (C8a), 171.8 (COO); HRMS calcd for $\left[\mathrm{C}_{14} \mathrm{H}_{24} \mathrm{O}_{3}+\mathrm{H}^{+}\right]$: 241.1798, found 241.1798 .

(4aS,8aS)-5-Methyl-2-oxo-3,4,4a,7,8,8a-hexahydrochromene (18): $[\alpha]^{22} \mathrm{D}-56.4$ (c, 1.0, $\left.\mathrm{CHCl}_{3}\right) ;{ }^{1} \mathrm{H} \mathrm{NMR}\left(\mathrm{CDCl}_{3}\right.$, $400 \mathrm{MHz}) \delta: 1.51-1.60(\mathrm{~m}, 1 \mathrm{H}), 1.67\left(\mathrm{~s}, 3 \mathrm{H}, \mathrm{CH}_{3}\right), 1.69-1.79$ $(\mathrm{m}, 1 \mathrm{H}), 2.06-2.20(\mathrm{~m}, 5 \mathrm{H}), 2.58-2.72(\mathrm{~m}, 1 \mathrm{H}), 2.76$ (ddd, $J=$ $18.1,8.8,3.5 \mathrm{~Hz}, 1 \mathrm{H}$ ), 4.14 (ddd, $J=12.4,9.3,3.3 \mathrm{~Hz}, 1 \mathrm{H}$ ), $5.41(\mathrm{~s}, 1 \mathrm{H}) ;{ }^{13} \mathrm{C} \mathrm{NMR}\left(\mathrm{CDCl}_{3}, 100.6 \mathrm{MHz}\right) \delta: 19.9\left(\mathrm{CH}_{3}\right), 23.5$ $\left(\mathrm{CH}_{2}\right), 24.4\left(\mathrm{CH}_{2}\right), 28.3\left(\mathrm{CH}_{2}\right), 29.9\left(\mathrm{CH}_{2}\right), 41.0(\mathrm{CH}), 81.3(\mathrm{CH})$, $122.8(\mathrm{CH}), 132.2(\mathrm{CH}), 171.9$ (COO); $\mathrm{MS}(\mathrm{Cl}) \mathrm{m} / \mathrm{z}(\%): 166.1$, $100(\mathrm{M}+)$.

(4aR,8aS)-2-Oxooctahydrochromene (19): $[\alpha]^{22} \mathrm{D}-39.2$ (c, 0.7, MeOH) $\left\{\right.$ Lit. $^{[13]}-40.5$ (c, 0.98, MeOH)\}; ${ }^{1} \mathrm{H}-\mathrm{NMR}$ $\left(\mathrm{CDCl}_{3}, 400 \mathrm{MHz}\right) \delta: 1.00-1.08(\mathrm{~m}, 1 \mathrm{H}), 1.19-1.30(\mathrm{~m}, 2 \mathrm{H})$, 1.36-1.54 $(\mathrm{m}, 3 \mathrm{H}), 1.67-1.71(\mathrm{~m}, 1 \mathrm{H}), 1.80-1.87(\mathrm{~m}, 3 \mathrm{H})$, 2.07-2.10 (m, 1H), 2.46-2.56 (m, 1H), 2.61-2.69 (m, 1H), 3.86 $(\mathrm{td}, J=10.2,4.3 \mathrm{~Hz}, 1 \mathrm{H}) ;{ }^{13} \mathrm{C}-\mathrm{NMR}\left(\mathrm{CDCl}_{3}, 400 \mathrm{MHz}\right) \delta: 24.2$ $\left(\mathrm{CH}_{2}\right), 25.2\left(\mathrm{CH}_{2}\right), 26.6\left(\mathrm{CH}_{2}\right), 29.9\left(\mathrm{CH}_{2}\right), 31.2\left(\mathrm{CH}_{2}\right), 32.4$ $\left(\mathrm{CH}_{2}\right), 38.9(\mathrm{CH}), 83.5(\mathrm{CH}), 171.7(\mathrm{COO})$.

\section{CONFLICT OF INTEREST}


The authors confirm that this article content has no conflict of interest.

\section{ACKNOWLEDGEMENTS}

Financial support from the MINECO/FEDER (Project CTQ2015-65384-R) and the Generalitat de Catalunya (Grant 2014-SGR-155) is gratefully acknowledged. We also acknowledge the MECD (Spain) for a fellowship to A. P., the Serra Hunter programme (R. G.), and the networking contribution from the COST Action CM1407.

\section{REFERENCES}

[1] Ghirardi, E.; Griera, R.; Piccichè, M.; Molins, E.; Fernández, I.; Bosch, J.; Amat, M. Org. Lett. 2016, 18, 5836-5839.

[2] Amat, M.; Ghirardi, E.; Navío, L.; Griera, R.; Llor, N.; Molins, E.; Bosch, J. Chem. Eur. J. 2013, 19, 16044-16049.

[3] (a) Amat, M.; Fabregat, R.; Griera, R.; Molins, E.; Bosch, J. Angew. Chem. Int. Ed. 2008, 47, 3348-3351; (b) Amat, M.; Fabregat, R.; Griera, R.; Florindo, P.; Molins, E.; Bosch, J. J. Org. Chem. 2010, 75, 3797-3805.

[4] Pinto, A.; Griera, R.; Molins, E.; Fernández, I.; Bosch, J.; Amat, M. Org. Lett. 2017, 19, 1714-1717.

[5] (a) Amat, M.; Pinto, A.; Griera, R.; Bosch, J. Chem. Comm. 2013, 49, 11032-11034; (b) Amat, M.; Pinto, A.; Griera, R.; Bosch, J. Chem. Eur. J. 2015, 21, 12804-12808.

[6] (a) Amat, M.; Cantó, M.; Llor, N.; Ponzo, V.; Pérez, M.; Bosch, J. Angew. Chem. Int. Ed. 2002, 41, 335-338; (b) Amat, M.; Fabregat, R.; Griera, R.; Bosch, J. J. Org. Chem. 2009, 74, 1794-1797.

[7] Amat, M.; Pérez, M.; Minaglia, A. T.; Bosch, J. J. Org. Chem., 2008, 73, 6920-6923.

[8] Oppolzer, W.; Fehr, C.; Warnecke, J. Helv. Chim. Acta, 1977, 60, 48-58.

[9] (a) Murahashi, S.-I.; Sasao, S.; Saito, E.; Naota, T. J. Org. Chem., 1992, 57, 2521-2523.; (b) Murahashi, S.-I.; Sasao, S.; Saito, E.; Naota, T. Tetrahedron, 1993, 49, 8805-8826.

[10] (a) Sugasawa, S.; Fujii, T. Chem. Pharm. Bull. 1958, 6, 587-590; (b) Ibuka, T.; Masaki, N.; Saji, I.; Tanaka, K.; Inubushi, Y. Chem. Pharm. Bull. 1975, 23, 2779-2790; (c) Revial, G.; Jabin, I.; Pfau, M. Tetrahedron: Asymmetry 2000, 11, 4975-4983; (d) Amat, M.; Pérez, M.; Llor, N.; Escolano, C.; Luque, J.; Molins, E.; Bosch, J. J. Org. Chem., 2004, 69, 8681-8693.

[11] For ${ }^{1} \mathrm{H}-\mathrm{NMR}$ data of cis- and trans-2-oxooctahydrochromenes, see: (a) Griffiths, D. V.; Wilcox, G., M.; J. Chem. Soc., Perkin Trans. 2, 1988, 431-436; (b) Forzato, C.; Nitti, P.; Pitacco, G.; Valentin, E. Tetrahedron: Asymmetry 1999, 10, 1243-1254; (c) Fogal, E.; Forzato, C.; Nitti, P.; Pitacco, G.; Valentin, E. Tetrahedron: Asymmetry 2000, 11, 2599-2614.

[12] Amat, M.; Navío, L.; Llor, N.; Molins, E.; Bosch, J. Org. Lett. 2012, 14, 210-213.
[13] Forzato, C.; Gandolfi, R.; Molinari, F.; Nitti, P.; Pitacco, G.; Valentin, E. Tetrahedron: Asymmetry 2001, 12, 1039-1046. 
Graphical abstract for use in the TOC

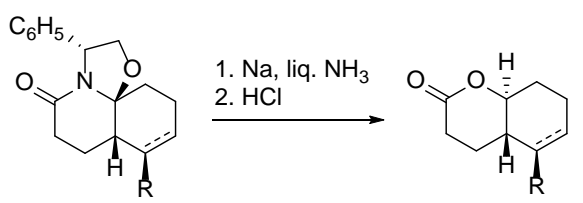

